\title{
EFFECTS OF AN ADDITION OF COIR-PITH PARTICLES ON THE MECHANICAL PROPERTIES AND EROSIVE-WEAR BEHAVIOR OF A WOOD-DUST-PARTICLE-REINFORCED PHENOL FORMALDEHYDE COMPOSITE
}

\author{
VPLIVI DODATKA KOKOSOVIH VLAKEN \\ FENOL-FORMALDEHIDNEMU KOMPOZITU, OJAČANEM Z \\ LESNIM PRAHOM, NA NJEGOVE MEHANSKE LASTNOSTI IN \\ EROZIJSKO OBRABO
}

\author{
Arul Sujin Jose', Ayyanar Athijayamani², Kalimuthu Ramanathan ${ }^{3}$, \\ Susaiyappan Sidhardhan ${ }^{4}$ \\ ${ }^{1}$ Lourdes Mount College of Engineering and Technology, Department of Mechanical Engineering, Kanyakumari, Tamilnadu, India \\ ${ }^{2}$ Government College of Engineering, Department of Mechanical Engineering, Bodinayakkanur, Tamilnadu, India \\ ${ }^{3}$ Alagappa Chettiar College of Engineering and Technology, Department of Mechanical Engineering, Karaikudi, Tamilnadu, India \\ ${ }^{4}$ Government College of Engineering, Department of Civil Engineering, Tirunelveli, Tamilnadu, India \\ athimania@gmail.com \\ Prejem rokopisa - received: 2016-09-23; sprejem za objavo - accepted for publication: 2017-01-22
}

doi: $10.17222 /$ mit.2016.284

Several attempts were made to investigate the effects of various process parameters on the mechanical properties and wear behavior of synthetic and natural cellulosic fibers and also particle-reinforced polymer composites. However, very few studies were carried out on the effects of various process parameters on the mechanical and wear behavior of phenol formaldehyde (PF) composites reinforced with natural cellulosic fibers and particles. Therefore, in the present study, an attempt was made to observe the effects of various process parameters on the mechanical and wear behavior of wood-dust (WD) and coir-pith (CP) particle-reinforced resole-type PF composites. First, the mechanical properties of a WD/PF composite were studied based on the content of CP particles. Then, the erosive-wear behavior of the WD/PF composite was studied with respect to five different parameters such particle content, erodent size, impact velocity, impingement angle, and standoff distance. The erosive experiments were carried out for five different parameters based on the Taguchi experimental design $\left(L_{27}\right)$. The results show that the mechanical properties of the WD/PF composite increase with an addition of CP particles. The increment in the composite modulus was higher than that of the composite strength. The erosive test results indicate that the erosion-wear rate is affected by the particle content, impingement angle, erodent size and impact velocity. Brittle-erosion behavior was identified on the surface of the composite with a heavy erosive wear occurring at a $60^{\circ}$ impingement angle.

Keywords: biowaste particles, phenol formaldehyde, composites, mechanical properties, erosive-wear resistance, Taguchi method

Izvedenih je bilo že kar nekaj poizkusov v zvezi z učinki različnih procesnih parametrov na mehanske lastnosti in obrabo polimernih kompozitov ojačanih s sintetičnimi in naravnimi celuloznimi vlakni in/ali delci. Toda zelo malo raziskav je bilo izvedenih glede vpliva različnih procesnih parametrov na mehanske lastnosti in obrabo fenolformaldehidnih (angl. PF) kompozitov, ojačanih z naravnimi celuloznimi vlakni in delci. Tako je v pričujočem delu predstavljen vpliv različnih procesnih parametrov na mehanske lastnosti in obrabo PF kompozitov, ki so bili ojačani z delci lesnega prahu (angl. WD) in delci kokosa (angl. CP). Te vrste kompozitov se uporabljajo za izdelavo podplatov čevljev. Najprej so bile določene mehanske lastnosti WD/PF kompozitov glede na vsebnost CP delcev. Sledili so preizkusi in analize erozijske obrabe WD/PF kompozitov glede na vsebnost (količino) delcev v kompozitu, velikost, hitrost in razdaljo učinkovanja erozijskega sredsta ter njegov vpadni kot. Preizkusi so temeljili na analizi s Taguchijevo metodo $\left(L_{27}\right)$ s petimi različnimi parametri. Rezultati so pokazali, da se mehanske lastnosti WD/PF kompozitov izboljšujejo z dodajanjem CP delcev. Povišanje modula kompozitov je bilo večje od povečanja trdnosti kompozita. Erozijski testi kažejo, da je hitrost erozijske obrabe posledica vseh procesnih parametrov, to je: vsebnosti delcev, udarnega kota, hitrosti in velikosti delcev izbranega erozijskega sredstva. Največja obraba zaradi erozije je bila dosežena (ugotovljena) pri 60 stopinjskem vpadnem kotu abrazijskega sredstva z nastalimi poškodbami krhkega značaja.

Ključne besede: delci bioodpadkov, fenolformaldehid, kompoziti, mehanske lastnosti, odpornost proti erozijski obrabi, Taguchi metoda

\section{INTRODUCTION}

Recently, polymer composites reinforced with synthetic materials have been replaced with polymer composites reinforced with bio-based natural materials. The bio-based natural materials have many advantages over the synthetic materials like renewability, biodegradability, abundant availability, low costs, etc. ${ }^{1-3}$ In India, particularly in the South Indian region, the biowaste materials like wood dust, coir pith, groundnut shell, coconut shell, cashew nut shell, etc. are abundantly available because in that region, coconut, groundnut and cashew nut are cultivated in large amounts. A number of timber and oil mills are also available in the Southern region of Tamilnadu, India. Therefore, bioparticles are thrown away after producing useful materials and 
dumped on the land of the village nearest to these industries.

Many studies have already reported on the properties of different bio-based natural-fiber-reinforced polymer composites in different conditions. ${ }^{3-7}$ But, only few reports are available on the properties of polymer composites filled with biowaste particles. ${ }^{8-11}$ In this investigation, an attempt was made to study the mechanical and wear behavior of PF composites reinforced with biowaste particles (WD and CP). Mechanical properties of wood-dust-particle-reinforced PF composites were evaluated based on the content of coir pith. The erosivewear behavior of the composites was studied using five different parameters such as particle content, erodent size, impingement angle, impact velocity and standoff distance. The erosive experiments were conducted as per the Taguchi experimental design. The parameters used for erosive-wear tests were also analyzed using an analysis of variance with the wear rate.

\section{MATERIALS AND METHODOLOGY}

\subsection{Materials}

Wood-dust particles were collected from the Kumar Timber and Sawmill, Karaikudi, Tamilnadu, India. Coir-pith particles were collected from the Coir Industry, Sozhavanthan, Tamilnadu, India. From the collected wood-dust and CP particles, microparticles with the average size of 800 microns were separated using a sieving machine available in our composite laboratory. The resole-type PF liquid resin was procured, together with a cross-linking agent (divinylbenzene) and acidic catalyst (hydrochloric acid), from POOJA Chemicals, Madurai, Tamilnadu, India.

\subsection{Preparation of the composites}

A hardboard mold box with dimensions of $150 \mathrm{~mm} \times$ $150 \mathrm{~mm} \times 3 \mathrm{~mm}$ was used to prepare the wood-dust and coir-pith-particle composite plates using the hand lay-up technique. Wood dust/coir pith/phenol formaldehyde composites were fabricated at three different concentrations of wood-dust and coir-pith particles, i.e., (20, 30 and 40) $\%$ mass fractions. The amount of WD particles was maintained at a fixed level of $20 \%$ mass fraction. Three different amounts of CP particles (0-20\% mass fractions) were hybridized with the constant amount of WD particles, i.e., 20WD/0CP, 20WD/10CP, 20WD/20CP. The weight percentage of WD and $\mathrm{CP}$ particles and designation of the composites are given in Table 1. Prior to the process, the particles were dried in sunlight for $12 \mathrm{~h}$. The PF resin with the particles was mixed with a mechanical stirrer at room temperature for $30 \mathrm{~min}$. Then, the cross-linking agent and acidic catalyst were also mixed into the mixture of phenol formaldehyde/particles and once again stirred with the mechanical stirrer for 15 min. After that, the mixture was poured into the mold box and allowed to cure at room temperature for $48 \mathrm{~h}$.

\subsection{Testing composite specimens}

Composite specimens were characterized using mechanical tests such as tensile, flexural and impact tests. The tensile tests were conducted on an FIE universal testing machine (UTE 40 HGFL) in accordance with ASTM D638-10. ${ }^{12}$ The flexural tests were performed on the same testing machine in accordance with ASTM D790-10. ${ }^{13}$ The impact tests were carried out on an Izod impact machine according to ISO $180 .{ }^{14}$ All the tests were conducted at room temperature and atmospheric pressure.

\subsection{Taguchi experimental design}

The erosive behavior of the WD/CP/PF composite was studied based on the Taguchi method and analysis of variance techniques. Experiments were performed as per Taguchi experimental design (an orthogonal array) because it is a systematic and efficient approach to get the optimum range of process parameters with a good performance. The number of experiments can be reduced due to the constructed orthogonal array, which provides a set of well-balanced experiments. ${ }^{15}$ The results obtained with this experimental design are transformed into signal-to-noise $(S / N)$ ratios, which serve as objective functions for the optimization of parameters and help with the result analysis. There are three $S / N$ ratios available for the optimization of several static problems: the smaller-the-better (used to minimize the response), the nominal-the-better (used whenever an ideal quality is equated with a particular nominal value.) and the largerthe-better ratio (used to maximize the response). Among these three characteristics, the minimum erosion rate comes under the smaller-the-better characteristic, which can be expressed as Equation (1):

$$
S / N=-10 \log _{10}
$$

(the mean of the sum of squares of the measured data)

Table 1: The weight percentage of WD and CP particles and designation of the composites

\begin{tabular}{|c|c|c|c|}
\hline $\begin{array}{c}\text { Total weight percentage } \\
\text { of particles in the } \\
\text { composites }\end{array}$ & $\begin{array}{c}\text { Weight percentage of } \\
\text { resin }\end{array}$ & $\begin{array}{c}\text { Weight percentage of } \\
\text { WD particles }\end{array}$ & $\begin{array}{c}\text { Weight percentage of } \\
\text { CP particles }\end{array}$ \\
\hline 20 & 80 & 20 & 0 \\
\hline 30 & 70 & 20 & 10 \\
\hline 40 & 60 & 20 & $20 \mathrm{WD} / 0 \mathrm{CP}$ \\
composites & $20 \mathrm{WD} / 20 \mathrm{CP}$ \\
\hline
\end{tabular}




\section{A. SUJIN JOSE: EFFECTS OF AN ADDITION OF COIR-PITH PARTICLES ON THE MECHANICAL AND ...}

The five different process parameters at three levels are used in this study to observe the erosive behavior of the $\mathrm{WD} / \mathrm{CP} / \mathrm{PF}$ composite. Therefore, the actual number of experiments, based on the traditional experimental design, should be $243\left(3^{5}\right)$. But, this number is reduced to 27 experiments using the Taguchi technique. The process parameters and their setting levels for the erosion test of the WD/CP/PF composite are presented in Table 2. In these experiments, the following parameters are fixed throughout the process: the type of erodent is silica, the erodent feed rate is $10.0 \pm 1.0 \mathrm{~g} / \mathrm{min}$, the nozzle length is $80 \mathrm{~mm}$, and the nozzle diameter is $3 \mathrm{~mm}$.

Table 2: The erosive process parameters with their designation and setting levels

\begin{tabular}{|l|c|c|c|}
\hline $\begin{array}{c}\text { Process Parameters and their } \\
\text { designation }\end{array}$ & Level I & Level II & Level III \\
\hline Particle content: (A) wt\% & 20 & 30 & 40 \\
\hline Impact velocity: (B) m/sec & 41 & 52 & 63 \\
\hline Impingement angle: (C) degree & 30 & 60 & 90 \\
\hline Erodent size: (D) $\mu \mathrm{m}$ & 300 & 500 & 700 \\
\hline Stand-off distance: (E) mm & 80 & 120 & 160 \\
\hline
\end{tabular}

\subsection{Erosion test}

The erosive tests of the WD/CP/PF composite specimens were conducted as shown in the schematic diagram of the erosion process (Figure 1). The main components of the erosion-test apparatus are the erodent feeder box, erodent feeder nozzle, mixing chamber, nozzle of the mixing chamber, air-flow vent, sample holder and erodent collector. Dry silica sand with three different sizes $(300,500$ and 700$) \mu \mathrm{m}$ was used as the erodent in the erosion tests. After the test, the composite samples were taken from the apparatus and cleaned with acetone.

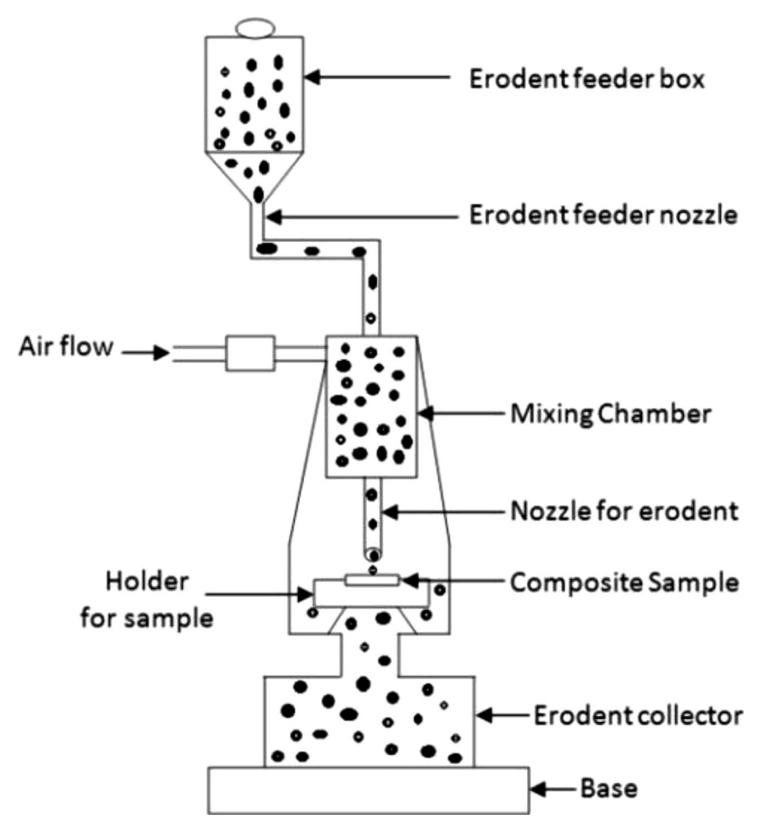

Figure 1: Schematic diagram of the erosive process of the WD/CP/PF composite
Then, the cleaned composite specimens were dried and weighed using a precision digital balance at an accuracy of $\pm 0.1 \mathrm{mg}$. The composite samples were weighed before and after the erosion tests and their difference is termed as the weight loss. Then, the weight loss was recorded and used for the erosion-rate calculation. Generally, the erosion rate can be obtained as the ratio of the weight loss of samples to the weight of the eroding particle. The process was repeated until the steady-state erosion was reached.

\section{RESULTS AND DISCUSSION}

\subsection{Mechanical properties of the composites}

Mechanical tests were carried out on the WD/CP/PF composites and their results are presented in Figure 2a. The neat-resin sample had a tensile strength of 29.8 MPa, tensile modulus of $1168.4 \mathrm{MPa}$, flexural strength of $34.7 \mathrm{MPa}$, flexural modulus of $1257.4 \mathrm{MPa}$, and impact strength of $1.24 \mathrm{KJ} / \mathrm{m}^{2}$. It can be seen that the tensile strength and modulus of the PF composite increase with an increase in the particle content. The tensile strength of the 20WD/PF composite is almost the same as that of the neat-resin sample. It shows that the addition of WD particles enhances the strength of the PF composite. The WD/PF composite without the addition of CP particles has a tensile strength of $30.4 \mathrm{MPa}$ and this value increases to $41.7 \mathrm{MPa}$ with the incorporation of $10 \%$ mass fraction of CP particles; after that, it decreases to $36.8 \mathrm{MPa}$ with the addition of $20 \%$ mass fraction of CP particles. This may be due to a poor interfacial bonding between the particles and the matrix, i.e., a weak transfer of stress. Moreover, the stress concentration in the PF matrix may be created due to the corner edges of the irregularly shaped WD and CP particles.

Due to the addition of $10 \%$ mass fraction and $20 \%$ mass fraction of $\mathrm{CP}$ particles, the tensile strength of the $\mathrm{WD} / \mathrm{PF}$ composite increases by about $37.17 \%$ and $21.1 \%$, respectively. Figure 2a also shows the tensilemodulus values of the $\mathrm{WD} / \mathrm{CP} / \mathrm{PF}$ composites with respect to the particle content. The composite also reached the tensile-modulus value of the neat-resin sample with the particle addition of $20 \%$ mass fraction. The tensilemodulus value of the WD/PF composite increased with the further addition of CP particles. The maximum modulus value was observed at $40 \%$ mass fraction of the particles.

The results of the flexural tests of the WD/CP/PF composites with respect to the particle content are given in Figure 2b. It is interesting to note that the flexural strength and modulus of the WD/PF composite increase with the addition of $\mathrm{CP}$ particles. The flexural strength of the WD/PF composite is slightly lower than the value of the neat-resin sample. The maximum values of the flexural strength and modulus were identified at the $40 \%$ addition. The flexural strength of the WD/PF composite 


\section{A. SUJIN JOSE: EFFECTS OF AN ADDITION OF COIR-PITH PARTICLES ON THE MECHANICAL AND ...}

was increased by about $68.99 \%$ due to the incorporation of $20 \%$ mass fraction of CP particles.

The impact-strength values of the WD/CP/PF composites after the impact tests are presented in Figure 2c. It can be seen that the impact strength of the WD/PF composite is slightly lower than the value of the neatresin sample. It is also shown that the impact strength of the WD/PF composite increases with the addition of 10 $\%$ mass fraction of CP particles, but it decreases with the incorporation of $20 \%$ mass fraction of CP particles. This may be due to a poor adhesion between the particles and the matrix. It may also be due to the stress concentration of the resin matrix. It is also observed that the incorporation of $10 \%$ mass fraction and $20 \%$ mass fraction of CP particles shows $15.57 \%$ and $8.19 \%$ higher impact values compared to the $\mathrm{WD} / \mathrm{PF}$ composite.

\subsection{Steady-state erosion: effects of the impingement angle}

Generally, the erosive-wear behavior of polymer composite materials can be categorized as brittle and ductile. A ductile erosive situation is created in thermoplastic polymer composites, whereas the a brittle erosive situation may be created in thermosetting polymer composites. For the steady-state-erosion analysis of the $\mathrm{WD} / \mathrm{CP} / \mathrm{PF}$ composites, an erosion test was carried out based on eight different impingement angles (20, 30, 40,
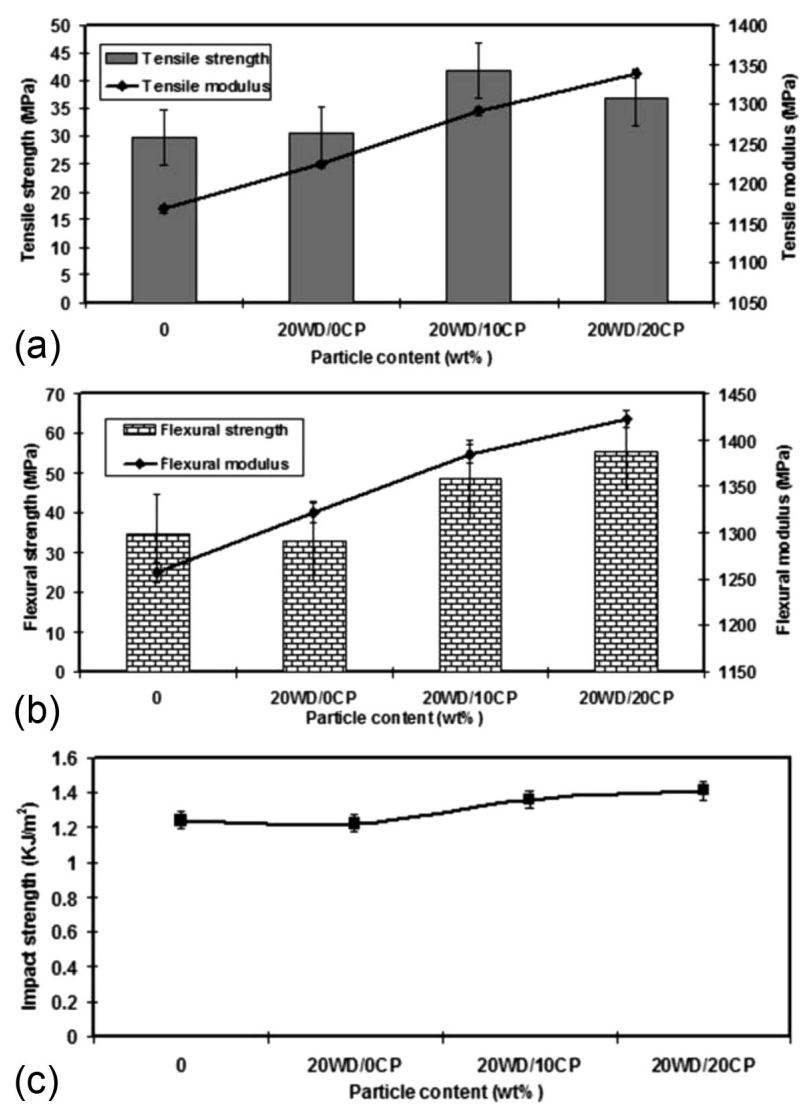

Figure 2: Variation of: a) tensile property, b) flexural property, and c) impact strength based on the particle content

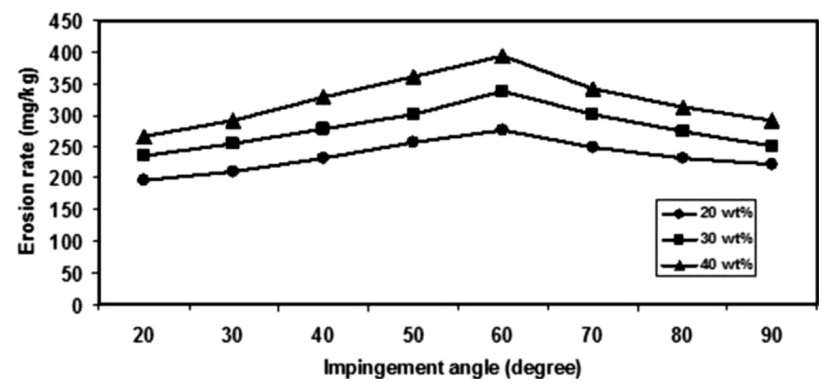

Figure 3: Steady-state erosive behavior of WD/CP/PF composites for eight different impingement angles

50, 60, 70, 80 and 90$)^{\circ}$, keeping all the other process parameters constant (the initial level values).

The effects of the impingement angles on the erosion rate of the WD/CP/PF composites are presented in Figure 3. From this figure, it can be observed that the erosion rate is high at the impingement angle of $60^{\circ}$ for all the composite specimens, irrespective of the particle content. However, a more brittle erosive behavior was identified for the $40 \%$ mass-fraction (20WD/20CP) composite specimen. However, in the $20 \%$ and $30 \%$ mass-fraction composite specimens, a semi-brittle erosive behavior was identified. This may be due to the addition of WD and CP particles to the PF composites. When the higher amounts of particles are added to the polymer material, it behaves as a typical brittle material. Therefore, the brittleness of the composites with $20 \%$ mass fraction and $30 \%$ mass fraction of particles is lower than the composite with $40 \%$ mass fraction of particles. Due to this, a semi-brittle erosive situation exists during the erosive process. It is also clear from Figure 3 that the erosion rate increased with the increase in the particle content. This may be due to the increased hardness of the PF composite material caused by the addition of WD and CP particles.

\subsection{Analysis of the erosion rate}

The erosion rates for 27 combinations of the erosive experiments conducted on the WD/CP/PF composites are given in Table 3. The erosion analysis was made with popular software, namely, MINITAB 17. From Table 3, it can be concluded that the parameter combination of particle loading-A (level II $=30 \%$ mass fraction), impact velocity-B (level $\mathrm{I}=41 \mathrm{~m} / \mathrm{s}$ ), impingement angle-C (level $\mathrm{I}=30^{\circ}$ ), erodent size-D (level II = 500 um) and standoff distance-E $(160 \mathrm{~mm})$ gives the minimum erosion rate $(189.8 \mathrm{mg} / \mathrm{kg})$. Moreover, another parameter combination (experiment number 4) allows the next level of the minimum erosion rate (194.1 $\mathrm{mg} / \mathrm{kg}$ ). The difference between these two erosion rates is small, as seen from Table 3. Anyway, the first parameter combination mentioned above is recognized as the better combination of parameters to obtain the minimum erosion rate. The overall mean of the signal-to-noise ratio for the erosion rate is found to be $49.75 \mathrm{~dB}$. 
A. SUJIN JOSE: EFFECTS OF AN ADDITION OF COIR-PITH PARTICLES ON THE MECHANICAL AND ...
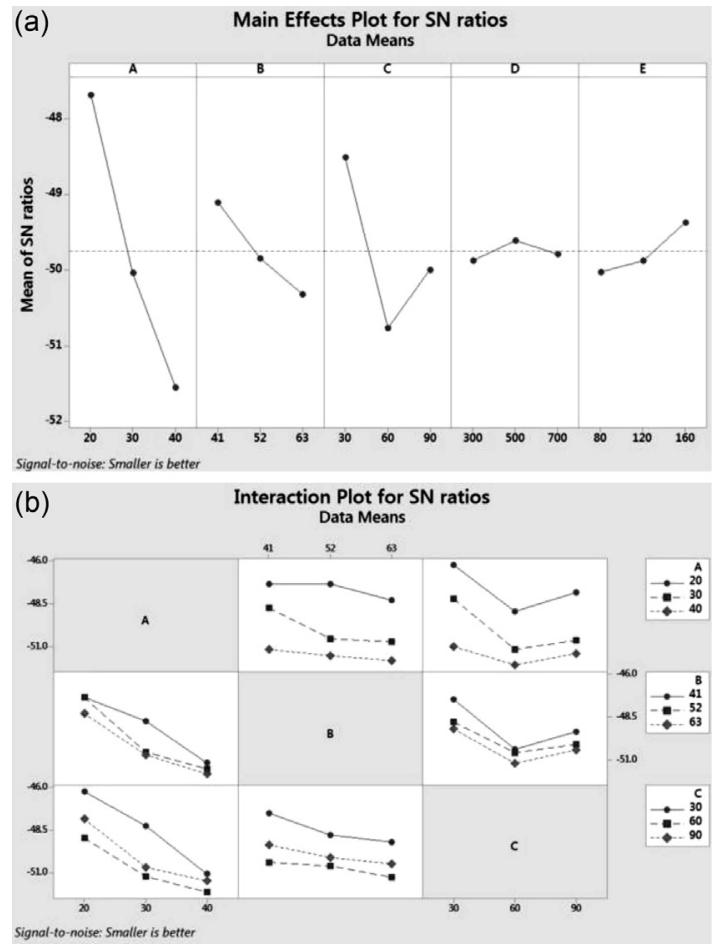

Figure 4: a) Effects of erosive-process parameters and b) effects of interactions of erosive-process parameters on the erosion rate

Table 3: The erosion rates and their $\mathrm{S} / \mathrm{N}$ ratio of $\mathrm{WD} / \mathrm{CP} / \mathrm{PF}$ composites for 27 combinations

\begin{tabular}{|c|c|c|c|c|c|c|c|}
\hline $\begin{array}{c}\text { Experi } \\
\text { ment } \\
\text { No. }\end{array}$ & $\mathrm{A}$ & $\mathrm{B}$ & $\mathrm{C}$ & $\mathrm{D}$ & $\mathrm{E}$ & $\begin{array}{c}\text { Erosion } \\
\text { rate } \\
\mathrm{mg} / \mathrm{kg}\end{array}$ & $\begin{array}{c}\text { S/N } \\
\text { ratio } \\
\mathrm{dB}\end{array}$ \\
\hline 1 & 20 & 41 & 30 & 300 & 80 & 209.5 & -46.42 \\
\hline 2 & 20 & 41 & 60 & 500 & 120 & 273.8 & -48.75 \\
\hline 3 & 20 & 41 & 90 & 700 & 160 & 220.7 & -46.87 \\
\hline 4 & 20 & 52 & 30 & 500 & 120 & 194.1 & -45.76 \\
\hline 5 & 20 & 52 & 60 & 700 & 160 & 267.3 & -48.54 \\
\hline 6 & 20 & 52 & 90 & 300 & 80 & 246.2 & -47.82 \\
\hline 7 & 20 & 63 & 30 & 700 & 160 & 211.9 & -46.52 \\
\hline 8 & 20 & 63 & 60 & 300 & 80 & 301.3 & -49.58 \\
\hline 9 & 20 & 63 & 90 & 500 & 120 & 277.1 & -48.85 \\
\hline 10 & 30 & 41 & 30 & 500 & 160 & 189.8 & -45.65 \\
\hline 11 & 30 & 41 & 60 & 700 & 80 & 343.5 & -50.72 \\
\hline 12 & 30 & 41 & 90 & 300 & 120 & 312.7 & -49.90 \\
\hline 13 & 30 & 52 & 30 & 700 & 80 & 298.9 & -49.51 \\
\hline 14 & 30 & 52 & 60 & 300 & 120 & 367.2 & -51.29 \\
\hline 15 & 30 & 52 & 90 & 500 & 160 & 351.3 & -50.91 \\
\hline 16 & 30 & 63 & 30 & 300 & 120 & 300.8 & -49.56 \\
\hline 17 & 30 & 63 & 60 & 500 & 160 & 378.5 & -51.56 \\
\hline 18 & 30 & 63 & 90 & 700 & 80 & 361.9 & -51.17 \\
\hline 19 & 40 & 41 & 30 & 700 & 120 & 332.8 & -50.44 \\
\hline 20 & 40 & 41 & 60 & 300 & 160 & 387.5 & -51.76 \\
\hline 21 & 40 & 41 & 90 & 500 & 80 & 370.6 & -51.37 \\
\hline 22 & 40 & 52 & 30 & 300 & 160 & 359.1 & -51.10 \\
\hline 23 & 40 & 52 & 60 & 500 & 80 & 398.3 & -52.00 \\
\hline 24 & 40 & 52 & 90 & 700 & 120 & 381.7 & -51.63 \\
\hline 25 & 40 & 63 & 30 & 500 & 80 & 379.2 & -51.58 \\
\hline 26 & 40 & 63 & 60 & 700 & 120 & 427.6 & -52.62 \\
\hline 27 & 40 & 63 & 90 & 300 & 160 & 369.8 & -51.36 \\
\hline & & & & & & & \\
\hline
\end{tabular}

The effects of five erosive-process parameters on the erosion rate are graphically presented in Figure 4a. From this figure, it can be clearly concluded that parameter A (the particle content), parameter B (the impact velocity) and parameter $C$ (the impingement angle) are the most significant parameters. Parameter E (the standoff distance) shows a moderately significant influence, while parameter D (the erodent size) has a relatively less significant influence. Figure $\mathbf{4 b}$ shows the interaction between the erosive parameters. From this figure, it is observed that a moderate interaction exists between parameters $\mathrm{A}$ and $\mathrm{B}$, and between $\mathrm{A}$ and $\mathrm{C}$. The interaction between parameters $\mathrm{B}$ and $\mathrm{C}$ is below the moderate level.

Figures 5a to $\mathbf{5 c}$ show 3D surface plots of the erosion rate with significant process parameters. The observation is similar to the one made of the interaction plots of the erosion rate. From the erosion test analysis of the WD/CP/PF composites, it can be concluded that the erodent size is most insignificant for the erosion rate. The standoff distance shows relatively less significance when compared to the other three process parameters (particle content, impact velocity and impingement

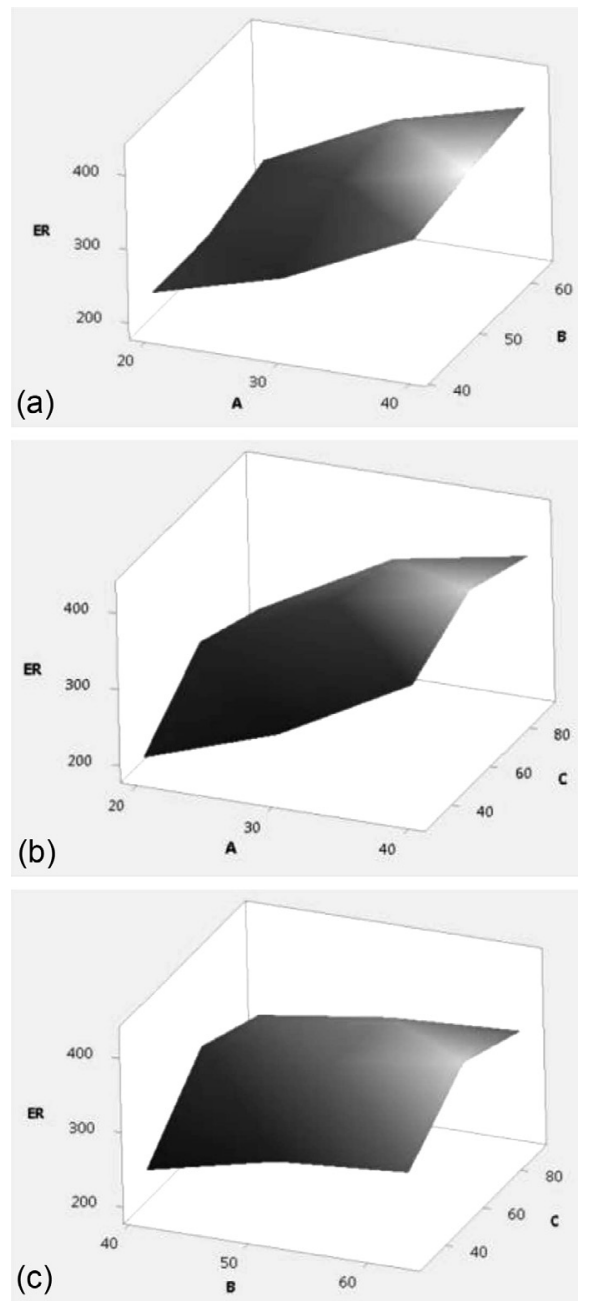

Figure 5: $3 \mathrm{D}$ surface plots of erosion rate vs process parameters: a) $\mathrm{A} \times \mathrm{B}$, b) $\mathrm{A} \times \mathrm{C}$, and c) $\mathrm{B} \times \mathrm{C}$ 


\section{A. SUJIN JOSE: EFFECTS OF AN ADDITION OF COIR-PITH PARTICLES ON THE MECHANICAL AND ...}

angle). It can be concluded that the combination of the parameters - the particle content at level II, the impact velocity at level I and the impingement angle at level I gives the minimum erosion rate. Therefore, this combination is recognized as the best combination of the erosive-process parameters to get the minimum erosion rate within the selected parameter range.

\subsection{Analysis of the variance for the erosion rate}

Taguchi's analysis of variance can be used to find the set of significant parameters as well as their interactions in any system. In this study, ANOVA is used to understand the contribution of the parameters to the erosion rate and the effects of their interactions on the erosion rate of the $\mathrm{WD} / \mathrm{CP} / \mathrm{PF}$ composite. The ANOVA results for the erosion rate of the $\mathrm{WD} / \mathrm{CP} / \mathrm{PF}$ composite are given in Table 4. The last column ( $p$-value) in this table indicates the highly significant parameters and their main effects depend upon the value of $p$. The $p$ values for the particle content, impact velocity, impingement angle and standoff distance are 0.000, 0.023, 0.003 and 0.186 , indicating their great influence on the erosion rate of the composite. The $p$ values of the interactions of the process parameters show a moderate significance and a significance below the moderate level. Table 5 shows the responses for the $S / N$ ratio (the small-the-better characteristic). The order of the erosive-process parameters based on their contributions to obtain the minimum erosion rate is the particle content, impingement angle, impact velocity, standoff distance and erodent size.

Table 4: Analysis of variance for Means of erosion rate

\begin{tabular}{|c|c|c|c|c|c|c|}
\hline Source & $D F$ & Seq SS & Adj SS & Adj MS & $F$ & $P$ \\
\hline A & 2 & 81404 & 81403.9 & 40701.9 & 120.99 & 0.000 \\
\hline B & 2 & 7520 & 7519.9 & 3759.9 & 11.18 & 0.023 \\
\hline C & 2 & 25188 & 25188.1 & 12594.0 & 37.44 & 0.003 \\
\hline D & 2 & 97 & 96.7 & 48.4 & 0.14 & 0.870 \\
\hline E & 2 & 1778 & 1778.4 & 889.2 & 2.64 & 0.186 \\
\hline A*B & 4 & 2698 & 2698.2 & 674.6 & 2.01 & 0.258 \\
\hline A*C & 4 & 3305 & 3305.3 & 826.3 & 2.46 & 0.203 \\
\hline B*C & 4 & 791 & 791.1 & 197.8 & 0.59 & 0.690 \\
\hline $\begin{array}{c}\text { Residual } \\
\text { Error }\end{array}$ & 4 & 1346 & 1345.6 & 336.4 & & \\
\hline Total & 26 & 124127 & & & & \\
\hline
\end{tabular}

Table 5: Response table for signal to noise ratios (smaller is better)

\begin{tabular}{|c|c|c|c|c|c|}
\hline Level & A & B & C & D & E \\
\hline 1 & -47.68 & -49.10 & -48.51 & -49.87 & -50.02 \\
\hline 2 & -50.03 & -49.84 & -50.76 & -49.61 & -49.87 \\
\hline 3 & -51.54 & -50.31 & -49.99 & -49.78 & -49.37 \\
\hline Delta & 3.86 & 1.21 & 2.25 & 0.26 & 0.65 \\
\hline Rank & 1 & 3 & 2 & 5 & 4 \\
\hline
\end{tabular}

\subsection{Confirmation experiment}

At the end of this study, we carried out a confirmatory experiment as the final test to validate the estimated results obtained during the erosive analysis of the $\mathrm{WD} / \mathrm{CP} / \mathrm{PF}$ composite. Therefore, the experimental results were verified with the estimated results using the confirmation test. This test was conducted to predict the erosion rate caused by a new set of erosive-processparameter levels $\left(\mathrm{A}_{2} \mathrm{~B}_{1} \mathrm{C}_{1} \mathrm{E}_{3}\right)$. To predict the $\mathrm{S} / \mathrm{N}$ ratio, the following equation can be used:

$$
S / N_{\mathrm{p}}=(\mathrm{A} 2-\mathrm{T})+(\mathrm{B} 1-\mathrm{T})+(\mathrm{C} 1-\mathrm{T})+(\mathrm{E} 3-\mathrm{T})+\mathrm{T}
$$

where $T$ is the overall experimental average of the $S / N$ ratio and $S / N_{\mathrm{p}}$ is the value of the predicted $\mathrm{S} / \mathrm{N}$ ratio. The comparison results for the predicted and experimental $S / N$ ratio of the optimum process parameters are given in Table 6. The difference between the predicted and experimental $S / N$ ratio is 0.51 , i.e., an error of $1.1 \%$. It proves that the model can predict the erosion rate with a reasonable accuracy.

Table 6: Comparison results of predicted and experimental signalto-noise ratio of optimal process parameters

\begin{tabular}{|c|c|c|c|}
\hline \multirow{2}{*}{} & \multicolumn{3}{|c|}{ Optimal erosive process parameters } \\
\cline { 2 - 4 } & Predicted & Experimental & Difference \\
\hline $\begin{array}{c}\text { Parameter } \\
\text { level }\end{array}$ & $\mathrm{A}_{2} \mathrm{~B}_{1} \mathrm{C}_{1} \mathrm{E}_{3}$ & $\mathrm{~A}_{2} \mathrm{~B}_{1} \mathrm{C}_{1} \mathrm{E}_{3}$ & $\begin{array}{c}\text { Predicted- } \\
\text { Experimental }\end{array}$ \\
\hline $\begin{array}{c}\text { Erosion rate } \\
\mathrm{mg} / \mathrm{kg}\end{array}$ & 191.5 & 189.8 & 1.7 \\
\hline $\begin{array}{c}\text { Signal-to-noise } \\
\text { ratio dB }\end{array}$ & -46.17 & -45.66 & \\
\hline
\end{tabular}

\section{CONCLUSIONS}

Mechanical properties of a WD/CP/PF composite were analyzed based on the particle content. The results show that the tensile strength of the WD/PF composite increased with the addition of $10 \%$ mass fraction of $\mathrm{CP}$ particles, but decreased with the addition of $20 \%$ mass fraction of $\mathrm{CP}$ particles. The flexural properties of the WD/PF composite increased with the increase in CP particles. The impact strength of the WD/PF composite also increased with the addition of $10 \%$ mass fraction of $\mathrm{CP}$ particles and decreased with further addition of $\mathrm{CP}$ particles. The steady-state erosion analysis was carried out for eight different impingement angles on the $\mathrm{WD} / \mathrm{CP} / \mathrm{PF}$ composite. The composite with the lower particle content shows a semi-brittle erosive behavior with a higher erosion wear at the $60^{\circ}$ impingement angle. On the other hand, the composite with the higher particle content showed a fully brittle nature of the erosive behavior with a higher erosion wear at the $60^{\circ}$ impingement angle. From the erosive analysis of the WD/CP/PF composite, the process parameters like the particle content, impingement angle and impact velocity are found to be the most significant parameters influencing the erosion rate. The standoff distance shows a moderate influence on the erosion rate, while the erodent size shows a less significant influence on the erosion rate. 


\section{MATERIALI IN TEHNOLOGIJE/MATERIALS AND TECHNOLOGY (1967-2017) - 50 LET/50 YEARS}

\section{A. SUJIN JOSE: EFFECTS OF AN ADDITION OF COIR-PITH PARTICLES ON THE MECHANICAL AND ...}

\section{REFERENCES}

${ }^{1}$ G. K. Mani, J. B. B. Rayappan, D. K. Bisoyi, Synthesis and characterization of kapok fibers and its composites, J. of Appl. Sci., 12 (2012), 1661-1665, doi:10.3923/jas.2012.1661.1665

${ }^{2}$ J. A. Khan, M. A. Khan, R. Islam, Mechanical, thermal and degradation properties of jute fabric - reinforced polypropylene composites: Effect of potassium permanganate as oxidizing agent, Polym. Compos., 34 (2013), 671-680, doi:10.1002/pc.22470

${ }^{3}$ S. Singh, D. Deepak, L. Aggarwal, V. K. Gupta, Tensile and flexural behavior of hemp fiber reinforced virgin recycled HDPE matrix composites, Procedia Mater. Sci., 6 (2014), 1696-1702, doi:10.1016/ j.mspro.2014.07.155

${ }^{4}$ I. V. Surendra, K. V. Rao, K. V. P. P. Chandu, Fabrication and investigation of mechanical properties of sisal, jute \& okra natural fiber reinforced hybrid polymer composites, Int. J. Eng. Trends Technol., 19 (2015), 116-120, doi: 10.14445/22315381/IJETT-V19P220

${ }^{5}$ D. Kurniawan, B. S. Kim, H. Y. Lee, J. Y. Lim, Effects of repetitive processing, wood content, and coupling agent on the mechanical, thermal, and water absorption properties of wood/polypropylene green composites, J. Adhes. Sci. Technol., 27 (2013), 1301-1312, doi:10.1080/01694243.2012.695948

${ }^{6}$ E. Muñoz, J. A. García-Manrique, Water absorption behaviour and its effect on the mechanical properties of flax fibre reinforced bioepoxy composites, Int. J. Polym. Sci., (2015), 1-10, doi:10.1155/ 2015/390275

${ }^{7}$ M. G. A. Selvan, A. Athijayamani, Mechanical properties of fragrant screwpine fiber reinforced unsaturated polyester composite: Effect of fiber length, fiber treatment and water absorption, Fibers Polym., 17 (2016), 104-116, doi:10.1007/s12221-016-5593-x

${ }^{8}$ S. I. Durowaye, G. I. Lawal, M. A. Akande, V. O. Durowaye, Mechanical properties of particulate coconut shell and palm fruit polyester composites, Int. J. Mater. Eng., 4 (2014), 141-147, doi:10.5923/j.ijme.20140404.04
${ }^{9}$ L. Netra, S. Thomas, C. K. Das, R. Adhikari, Analysis of morphological and mechanical behaviours of bamboo flour reinforced polypropylene composites, Nepal J. Sci. Technol., 13 (2012), 95-100, doi:10.3126/njst.v13i1.7447

${ }^{10}$ M. A. M. M. Idrus, S. Hamdan, M. R. Rahman, M. S. Islam, Treated tropical wood sawdust-polypropylene polymer composite: mechanical and morphological study, J. Biomater. Nano-Biotechnol., 2 (2011), 435-444, doi:10.4236/jbnb.2011.24053

${ }^{11}$ R. Panneerdhass, A. Gnanavelbabu, K. Rajkumar, Mechanical properties of luffa fiber and ground nut reinforced epoxy polymer hybrid composites, Procedia Eng., 97 (2014), 2042-2051, doi:10.1016/ j.proeng.2014.12.447

${ }^{12}$ ASTM D 638-10, Standard test method for tensile properties of plastics, Annual Book of ASTM Standards, 08.01 (2010), 1-16, ASTM International, West Conshohocken

${ }^{13}$ ASTM D 790-10, Standard test methods for flexural properties of un-reinforced and reinforced plastics and electrical insulating materials, Annual Book of ASTM Standards, 08.01 (2010), 1-11, ASTM International, West Conshohocken

${ }^{14}$ ISO 180:2000, Plastics - determination of Izod impact strength, third edition, ISO Central Secretariat, Switzerland, 2000

${ }^{15}$ U. S. Rao, L. L. R. Rodrigues, Influence of machining parameters on tool wear in drilling of GFRP composites -Taguchi analysis and ANOVA methodology, Proc. of the Inter. Conf. on Advances in Mechanical and Robotics Engineering - MRE 2014, 25-29, doi:10.15224/978-1-63248-002-6-84 